\title{
Originals
}

\section{Glucagon Physiology and Aging: Evidence for Enhanced Hepatic Sensitivity}

\author{
D. C. Simonson and R.A. DeFronzo \\ Department of Internal Medicine, Yale University School of Medicine, New Haven, Connecticut, USA
}

\begin{abstract}
Summary. To evaluate the role of abnormal glucagon physiology in the glucose intolerance of aging, we have examined: (1) basal glucagon concentration, (2) suppression of plasma glucagon by hyperglycaemia and hyperinsulinaemia, (3) plasma glucagon response to intravenous alanine, (4) glucagon kinetics, and (5) hepatic sensitivity to glucagon $\left(3 \mathrm{ng} \cdot \mathrm{kg}^{-1} \cdot \mathrm{min}^{-1}\right.$ for $3 \mathrm{~h}$ ) using $3-{ }^{3} \mathrm{H}$-glucose in young ( $24 \pm 1$ years), middleaged ( $41 \pm 2$ years), and older ( $62 \pm 2$ years) subjects. Fasting plasma glucagon levels in 58 young, 21 middle-aged, and 32 older subjects were $89 \pm 10,91 \pm 12$, and $96 \pm 21 \mathrm{pg} / \mathrm{ml}$, respectively ( $p=\mathrm{NS}$ ). Following elevation of plasma glucose to 2.2-6.9 mmol/1 above basal for $2 \mathrm{~h}$ (hyperglycaemic clamp technique), young, middle-aged, and older subjects showed similar depressions in plasma glucagon levels during all three studies. Elevation of the plasma insulin concentration to approximately $100 \mathrm{mU} / \mathrm{I}$ while maintaining euglycaemia (insulin clamp technique) also resulted in a similar decline in plasma glucagon levels in both young and older subjects (by $25 \pm 3$ and $27 \pm 3 \mathrm{pg} / \mathrm{ml}$ respectively). Following intravenous alanine infusion, the increase in plasma glucagon was not significantly different in young compared with older subjects $(65 \pm 16$ versus $38 \pm 7 \mathrm{pg} / \mathrm{ml})$. Plasma insulin $(7 \pm 1$ versus $8 \pm 1 \mathrm{mU} / \mathrm{l})$ and glucose $(0.33 \pm 0.11$ versus $0.50 \pm 0.11 \mathrm{mmol} / \mathrm{l})$ responses
\end{abstract}

were comparable in young and older subjects. During continuous glucagon infusion, the steady-state plasma glucagon concentration ( $267 \pm 32$ versus $252 \pm 12 \mathrm{pg} / \mathrm{ml}$ ) and the metabolic clearance rate of glucagon (16 \pm 1 versus $15 \pm 1 \mathrm{ml}$. $\mathrm{kg}^{-1} \cdot \min ^{-1}$ ) were similar in young and older subjects. However, the increase in plasma glucose concentration was significantly greater in the older than young subjects $(\Delta=1.17 \pm$ 0.11 versus $0.67 \pm 0.06 \mathrm{mmol} / 1, p<0.01)$. Basal glucose production in older subjects $\left(0.13 \pm 0.01 \mathrm{mmol} \cdot \mathrm{kg}^{-1} \cdot \mathrm{min}^{-1}\right)$ was slightly less than in the young $\left(0.15 \pm 0.01 \mathrm{mmol} \cdot \mathrm{kg}^{-1}\right.$. $\min ^{-1}$ ). However, the rise in glucose production following glucagon was significantly greater in older than young subjects $(31 \pm 5$ versus $18 \pm 4 \%, p<0.05)$. In conclusion, (1) basal glucagon levels are not consistently elevated in older subjects, (2) glucagon suppression by both hyperglycaemia and hyperinsulinaemia is similar in young and older subjects, (3) $\alpha$ cell sensitivity to alanine is not affected by age, (4) the metabolic clearance rate of glucagon is similar in young and older subjects, and (5) hepatic sensitivity to a physiological increment in plasma glucagon is increased in older subjects.

Key words: Glucagon, aging, glucose tolerance, insulin clamp, hyperglycaemic clamp.
The decline in glucose tolerance with advancing age is well established [1-5], but the mechanisms underlying this deterioration are unclear. Recently, both Berger et al. [6] and Marco et al. [7] have reported, in preliminary studies, higher fasting glucagon levels in healthy subjects over the age of 60 years compared to subjects in their twenties. Marco et al. [7] also documented impaired glucagon suppression after oral glucose and higher plasma glucagon levels following arginine stimulation. While these studies indicate that elevated levels of glucagon may be present in the elderly, it is not known if this is secondary to augmented $\alpha$ cell function and/or diminished clearance of glucagon. It is not therefore possible to conclude what effects, if any, this putative elevation in glucagon in older subjects might have on glucose tolerance. To answer this we have examined the effect of age on (1) fasting glucagon levels, (2) glucagon suppression during sustained hyperglycaemia, (3) glucagon suppression during euglycaemic hyperinsulinaemia, (4) glucagon stimulation by intravenous alanine, (5) the metabolic clearance rate of glucagon, and (6) hepatic sensitivity to glucagon.

\section{Subjects and Methods}

\section{Subjects}

Three groups of healthy adult volunteers were studied. The young group $(n=58)$ included 33 males and 25 females, aged $21-29$ years (mean $24 \pm 1$ years); the middle age group $(n=21)$ included 12 males 
and nine females, aged $30-49$ years (mean $41 \pm 2$ years); and the older group $(n=32)$ included 14 males and 18 females, aged $50-75$ years (mean $=62 \pm 2$ years). (The word 'older' has been used for convenience and many of these subjects would not be considered old by current day standards.) The hyperglycaemic clamp studies were performed on 33 of the young subjects (mean $25 \pm 1$ years), 18 middle aged subjects (mean $41 \pm 2$ years), and 11 older subjects (mean $58 \pm 3$ years). The euglycaemic insulin clamp studies were performed on 21 young subjects (mean $25 \pm 1$ years) and 15 older subjects (mean $64 \pm 2$ years). The alanine infusion was conducted in nine young (mean $23 \pm 1$ years) and eight older subjects (mean $63 \pm 3$ years). The glucagon infusion was performed on ten young (mean $23 \pm 1$ years) and eight older subjects (mean $63 \pm 3$ years). The volunteers were obtained locally and none had any unusual food consumption or exercise patterns. All were in good general health with no history of endocrine, renal, hepatic, or cardiovascular disease, and none had a family history of diabetes mellitus. They were all within $15 \%$ of ideal body weight based on the Metropolitan Life Insurance Tables, 1959. Oral glucose tolerance tests were not routinely performed. All subjects had fasting plasma glucose concentrations within the normal range (3.6- $5.8 \mathrm{mmol} / 1$ ). For 3 days before the study, participants consumed a weight-maintaining diet containing at least $200 \mathrm{~g}$ of carbohydrate, and none were on any medication. All studies were performed in the postabsorptive state at $08: 00 \mathrm{~h}$ following a 12 - $\mathrm{h}$ overnight fast. The purpose and potential risks of the study were carefully explained to all subjects and written voluntary consent was obtained before their participation.

\section{Hyperglycaemic Clamp Study}

Before each study a polyethylene catheter was inserted into a forehand vein under local xylocaine anaesthesia and patency maintained with a slow infusion of normal saline. The subject's hand was placed in a box heated to an air temperature of $70 \pm 2^{\circ} \mathrm{C}$ to ensure arterialization of venous blood [8]. A second catheter was introduced into an antecubital vein for glucose administration. Following a 30-min equilibration period, four baseline samples were drawn at 5-min intervals and analyzed for glucagon and insulin. A priming infusion of glucose was then administered in a logarithmically falling manner over $15 \mathrm{~min}$ to raise acutely the plasma glucose concentration to the desired hyperglycaemic plateau $(2.2 \mathrm{mmol} / \mathrm{l}$ or $6.9 \mathrm{mmol} / 1$ above basal). Plasma glucose was measured every $5 \mathrm{~min}$ and a variable glucose infusion adjusted to maintain it constant at the desired hyperglycaemic goal for $2 \mathrm{~h}$. Adjustment of the glucose infusion rate is based on a servo-control negative feedback principle [9]. Blood samples for glucagon and insulin were obtained at $10-15 \mathrm{~min}$ intervals throughout the 2 -h study period.

\section{Euglycaemic Insulin Clamp Study}

Polyethylene catheters were inserted into a hand and antecubital vein as described previously. After collection of four baseline blood samples, a prime plus continuous infusion of crystalline porcine insulin (Eli Lilly, Indianapolis, Indiana, USA) was administered to obtain constant hyperinsulinaemia [10]. The priming dose was administered in a logarithmically falling manner over $10 \mathrm{~min}$ at which time the continuous insulin infusion was begun. The total amount of insulin infused during the priming period was twice that infused during subsequent 10 -min intervals. The continuous infusion $\left(42.6 \mathrm{mU} / \mathrm{m}^{2}\right.$ surface area per min) was maintained for $110 \mathrm{~min}$. To prevent insulin absorption to glassware and to plastic infusion apparatus, infusates were prepared with the addition of $2 \mathrm{ml}$ of the subject's whole blood per $50 \mathrm{ml}$ of infusate. The plasma glucose level was maintained at basal pre-infusion levels by determination of the plasma glucose every 5 min and the periodic adjustment of a variable infusion of a $20 \%$ glucose solution as described for the hyperglycaemic clamp technique. Samples for glucagon and insulin analysis were taken at $10-15 \mathrm{~min}$ intervals.

\section{Alanine Infusion}

Following insertion of a polyethylene catheter into an antecubital vein, three baseline samples for glucose, glucagon, and insulin were obtained at 5-10 min intervals for the first hour and at 30-min intervals during the second hour.

\section{Glucagon Infusion}

Before the study, polyethylene catheters were inserted into both antecubital veins for blood sampling and infusion of $3-{ }^{3} \mathrm{H}$-glucose and glucagon. Glucagon was obtained from Eli Lilly, Indianapolis, Indiana, USA and had been shown to be free of any contaminating substances. For $3 \mathrm{~h}$ before initiating the glucagon infusion, each subject's glucose pool was labelled by a prime-continuous infusion of $3{ }^{3} \mathrm{H}$-glucose (New England Nuclear, Boston, Mass, USA). The labelled glucose was administered as an initial intravenous priming dose $(25 \mu \mathrm{Ci})$ followed immediately by a continuous intravenous infusion at a rate of $0.25 \mu \mathrm{Ci} / \mathrm{min}$. Plasma samples for determination of glucose specific activity were taken at 30-min intervals for the first $2 \mathrm{~h}$ and at $10-15 \mathrm{~min}$ intervals for the subsequent hour. A steady-state plateau of glucose specific activity was achieved in all subjects during the third hour of $3-{ }^{3} \mathrm{H}$-glucose infusion, and this plateau value was used to calculate basal hepatic production. After $3 \mathrm{~h}$ of continuous $3-{ }^{3} \mathrm{H}$-glucose infusion, glucagon was administered at a constant rate of $3 \mathrm{ng} \cdot \mathrm{kg}^{-1}$. $\mathrm{min}^{-1}$ for $180 \mathrm{~min}$. During the glucagon infusion, plasma samples for glucagon and insulin concentration and $3-{ }^{3} \mathrm{H}$-glucose specific activity were obtained at 5-15 min intervals during the first $90 \mathrm{~min}$ and at $30 \mathrm{~min}$ intervals for the last $90 \mathrm{~min}$. Glucagon was infused in normal saline containing human serum albumin at a final concentration of $588 \mathrm{ng} / \mathrm{ml}$ of infusate.

\section{Analytical Procedures}

Plasma glucose concentration was determined by the glucose oxidase method (Glucostat, Beckman Instruments, Fullerton, California, USA). Methods for the determination of plasma immunoreactive glucagon (with Unger antibody $30 \mathrm{~K}$ ) and insulin [11] and the specific activity of plasma glucose [12] have been described previously. The Unger $30 \mathrm{~K}$ antibody primarily reflects the biologically active 3500 molecular weight glucagon species.

\section{Calculations}

The metabolic clearance rate of glucagon was calculated by dividing the continuous glucagon infusion rate $\left(3 \mathrm{ng} \cdot \mathrm{kg}^{-1} \cdot \mathrm{min}^{-1}\right)$ by the mean increment above basal in plasma glucagon concentration during the $40-180 \mathrm{~min}$ time period. Glucose production in the basal state was determined by dividing the $3-{ }^{3} \mathrm{H}$-glucose infusion rate $(\mathrm{cpm})$ by the steady-state plateau of $3-{ }^{3} \mathrm{H}$-glucose specific activity (counts $/ \mathrm{mg}$ ) achieved during the last hour of the pre-glucagon infusion period. Basal glucose clearance was determined by dividing the infusion rate of ${ }^{3} \mathrm{H}$-3-glucose (cpm) by the steady-state plateau of ${ }^{3} \mathrm{H}-3$-glucose counts (counts $/ \mathrm{ml}$ ). Because renal glucose production is negligible in the post-absorptive state, the rate of glucose appearance was assumed to be equivalent to the rate of hepatic glucose production. Furthermore, since plasma glucose concentration is held constant at the basal state, the rate of glucose uptake by all of the tissues of the body must be equal to the rate of hepatic glucose production. After glucagon administration, a non-steady-state condition in glucose specific activity exists. Rates of hepatic glucose production, glucose utilization and glucose clearance were then calculated by Steele's equations in their derivative form [13], which permit the evaluation of continuous changes in the rates of glucose turnover. The value of 0.65 was used as the pool fraction in the present calculations [14]. The determination of glucose turnover by the primed constant infusion and pool-fraction technique has been validated for both steady and non-steady states [15]. 


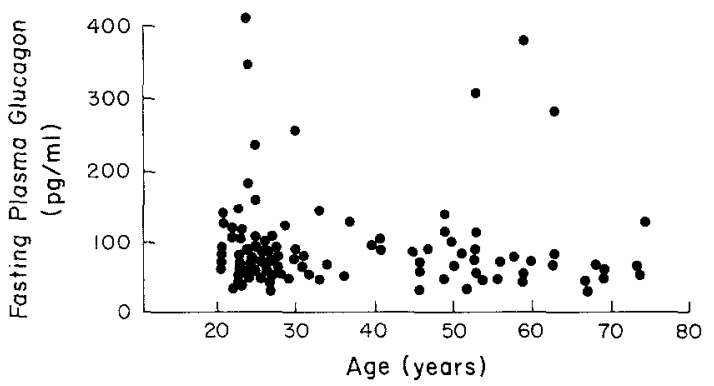

Fig. 1. Age versus fasting plasma glucagon concentration in 111 normal subjects

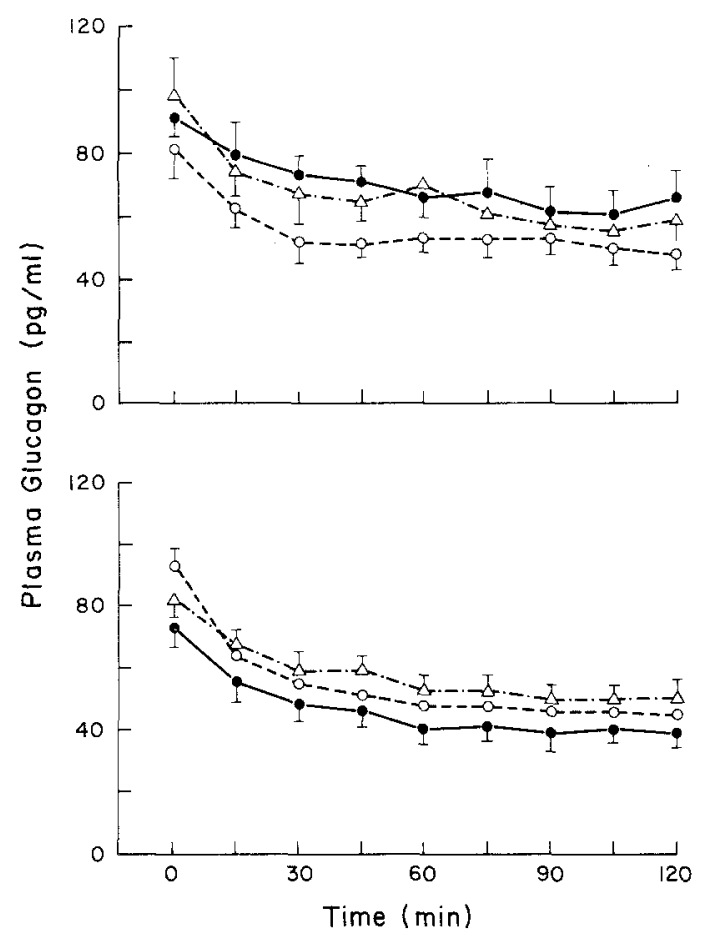

Fig. 2. Plasma glucagon concentration in young $\left(\mathrm{O}_{--} \mathrm{O}\right)$, middleaged $(\Delta-\cdot-\Delta)$, and older $(-0)$ subjects following elevation of the plasma glucose concentration to $2.2 \mathrm{mmol} / 1$ (upper panel) and $6.9 \mathrm{mmol} / 1$ (lower panel) above basal levels. All values represent the mean \pm SEM

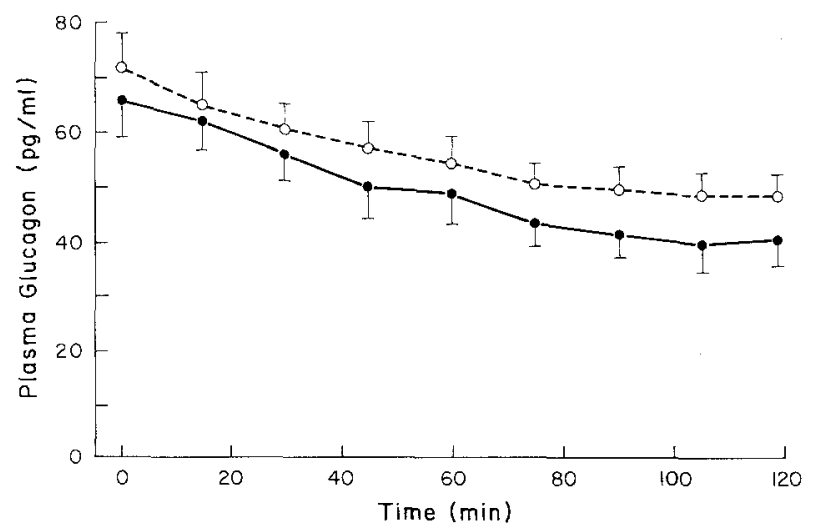

Fig. 3. Plasma glucagon concentration in young $\left(\mathrm{O}_{--} \mathrm{O}\right)$ and older (-) subjects during sustained euglycaemic hyperinsulinaemia. All values represent the mean $\pm S E M$
All data are presented as mean \pm SEM. Statistical comparisons between groups were calculated by unpaired t-test analysis and analysis of variance [16]. Coefficients of correlation were determined by standard procedures [16].

\section{Results}

\section{Basal Glucagon Levels}

Fasting glucagon levels were obtained in 58 young, 21 middle-aged, and 32 old subjects. Where volunteers participated in more than one study, basal glucagon levels were determined by obtaining the mean of the fasting levels of all studies in which they participated. The mean \pm SEM fasting glucagon levels in young, middleaged, and older subjects were $89 \pm 10,91 \pm 12$ and $96 \pm$ $21 \mathrm{pg} / \mathrm{ml}$, respectively. No significant correlation $(r=$ $-0.08, p>0.4$ ) was observed between age and the fasting plasma glucagon concentration in the 111 subjects (Fig. 1).

\section{'Hyperglycaemic Clamp' Studies}

Twenty young, 15 middle-aged, and 10 older subjects received a glucose increment of $6.9 \mathrm{mmol} / 1$. The mean plasma insulin and steady-state glucose concentrations during the 2 -h study period were $70 \pm 6,68 \pm 5$, and $63 \pm 5 \mathrm{mU} / 1$ and $11.89 \pm 0.01,12.11 \pm 0.01$ and $12.11 \pm$ $0.01 \mathrm{mmol} / 1$, respectively, in the young, middle, and older-aged groups. The stability of the plasma glucose concentration is indicated by the coefficient of variation which averaged $3.8 \pm 0.2,3.9 \pm 0.2$, and $3.5 \pm 0.3 \%$ in the three groups.

Within 30 to $45 \mathrm{~min}$ of the onset of hyperglycaemia, all groups had attained their maximum decline in plasma glucagon concentrations and these depressed levels were maintained until the end of the study (Fig. 2). The absolute change from baseline in glucagon levels for young, middle-aged, and old subjects were $44 \pm 4,32 \pm 6$ and $32 \pm 5 \mathrm{pg} / \mathrm{ml}$, respectively. The percentage suppression was also similar in young $(46 \pm 3 \%)$, middle-aged $(35 \pm 5 \%)$, and old $(42 \pm 2 \%)$ subjects.

When the plasma glucose concentration was raised and maintained at $2.2 \mathrm{mmol} / 1$ above basal in 14 young, seven middle-aged, and six older subjects, a rapid decrease in plasma glucagon concentration was again observed during the first $30 \mathrm{~min}$ and reached maximal suppression during the second hour (Fig. 2). The maximal absolute as well as the percentage suppression in plasma glucagon levels were similar in all three age groups.

\section{'Euglycaemic Insulin Clamp' Studies}

Twenty-one young and 15 old subjects underwent an insulin clamp study at a rate of $1 \mathrm{mU} \cdot \mathrm{kg}^{-1} \cdot \mathrm{min}^{-1}$ (Fig.3). The mean steady-state plasma insulin concentration in the young and old subjects was $112 \pm 4$ and $119 \pm 4 \mathrm{mU} / 1$ respectively with coefficients of variation 

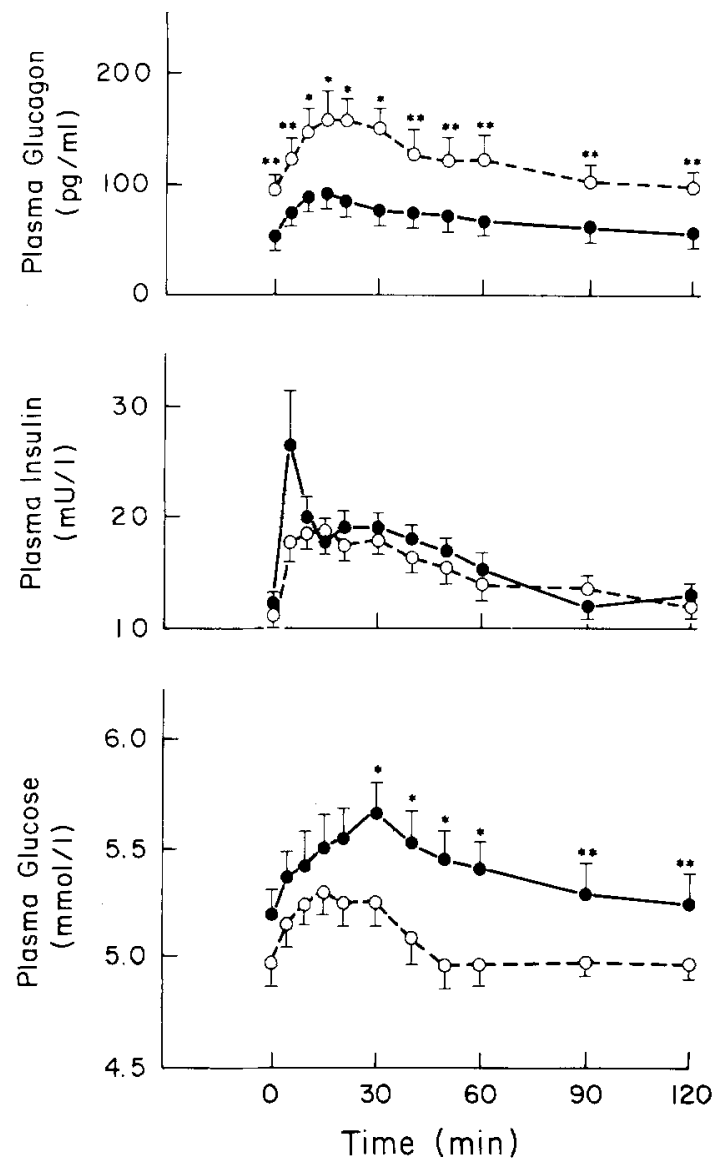

Fig.4. Plasma glucagon, insulin, and glucose levels in young $\left(\mathrm{O}_{-} \mathrm{O}\right)$ and older $(-)$ subjects following intravenous alanine. All values represent the mean \pm SEM. $* * p<0.05 ; * p<0.01$ (young versus older)

of $9.3 \pm 0.7 \%$ and $8.8 \pm 0.6 \%$. The plasma glucose concentration was maintained within $98 \pm 2 \%$ of the basal pre-infusion level in the young subjects and within $99 \pm 1 \%$ in the older group. The stability of the plasma glucose concentration in both groups is indicated by the small coefficients of variation, $4.7 \pm 0.2 \%$ and $3.8 \pm 0.2 \%$, respectively.

There was a progressive decline in plasma glucagon concentration during the first $60-80 \mathrm{~min}$ following insulin administration in both young and older groups. Thereafter, plasma glucagon levels remained relatively constant. There were no significant differences in the plasma glucagon levels between young and older subjects at any time point. The absolute reductions from baseline in glucagon levels for young and older subjects were $25 \pm 3$ and $27 \pm 3 \mathrm{pg} / \mathrm{ml}$, respectively.

\section{Alanine Infusion}

The plasma glucose, glucagon, and insulin responses to an intravenous bolus of $\mathrm{L}$-alanine were examined in nine young and eight older subjects (Fig. 4). The fasting levels of glucose $(5.00 \pm 0.17$ versus $5.22 \pm 0.17 \mathrm{mmol} / 1)$ and the maximal increases in plasma glucose $(0.33 \pm$
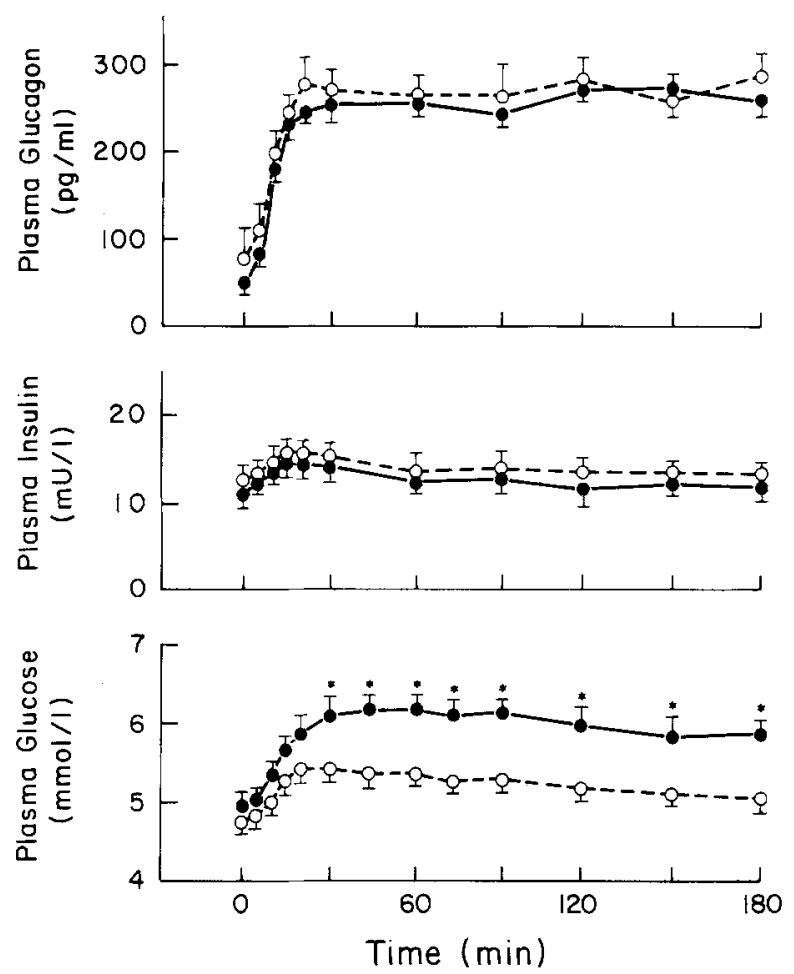

Fig.5. Plasma glucagon, insulin, and glucose concentrations in young $(\mathrm{O}-\mathrm{O})$ and older $(-)$ ) subjects during continuous glucagon infusion $\left(3 \mathrm{ng} \cdot \mathrm{kg}^{-1} \cdot \mathrm{min}^{-1}\right)$. All values represent the mean $\pm \mathrm{SEM}$. $* p<0.01$ (young versus older)

0.11 versus $0.50 \pm 0.11 \mathrm{mmol} / \mathrm{l})$ were not significantly different between young and older subjects. However, the plasma glucose concentration returned to baseline by $50 \mathrm{~min}$ in the younger group, but required $120 \mathrm{~min}$ to return to basal levels in the older subjects. This difference between the groups in the shape of the glucose response curves was statistically highly significant by analysis of variance $(p<0.005)$.

The mean basal glucagon levels for the young and older groups were $94 \pm 13$ and $53 \pm 4 \mathrm{pg} / \mathrm{ml}(p<0.02)$. The maximal rise in plasma glucagon above basal after stimulation by alanine was slightly, although not significantly, higher in the young $(65 \pm 16 \mathrm{pg} / \mathrm{ml})$ versus older $(38 \pm 7 \mathrm{pg} / \mathrm{ml})$ subjects. The percentage increase from basal levels was similar in young $(71 \pm 21 \%)$ and older $(79 \pm 16 \%)$ subjects.

There was no detectable difference in fasting insulin levels between the young and old subjects in this study $(12 \pm 1$ versus $12 \pm 1 \mathrm{mU} / 1)$. Five minutes after alanine administration, there was a slightly greater increase in the plasma insulin concentration in the older $(15 \pm 4$ $\mathrm{mU} / \mathrm{l})$ versus young $(6 \pm 1 \mathrm{mU} / \mathrm{l})$ subjects $(0.10>p>$ 0.05 ). The magnitude of the rise in the older group at 5 min was greatly influenced by two subjects who increased their basal levels by 38 and $27 \mathrm{mU} / 1$, whereas the remaining six individuals in the older group exhibited a mean rise of $9 \pm 1 \mathrm{mU} / 1$ (range $7-13 \mathrm{mU} / 1$ ). At all times subsequent to the 5-min value, the plasma insulin levels were similar in the young and old subjects (Fig.4). 

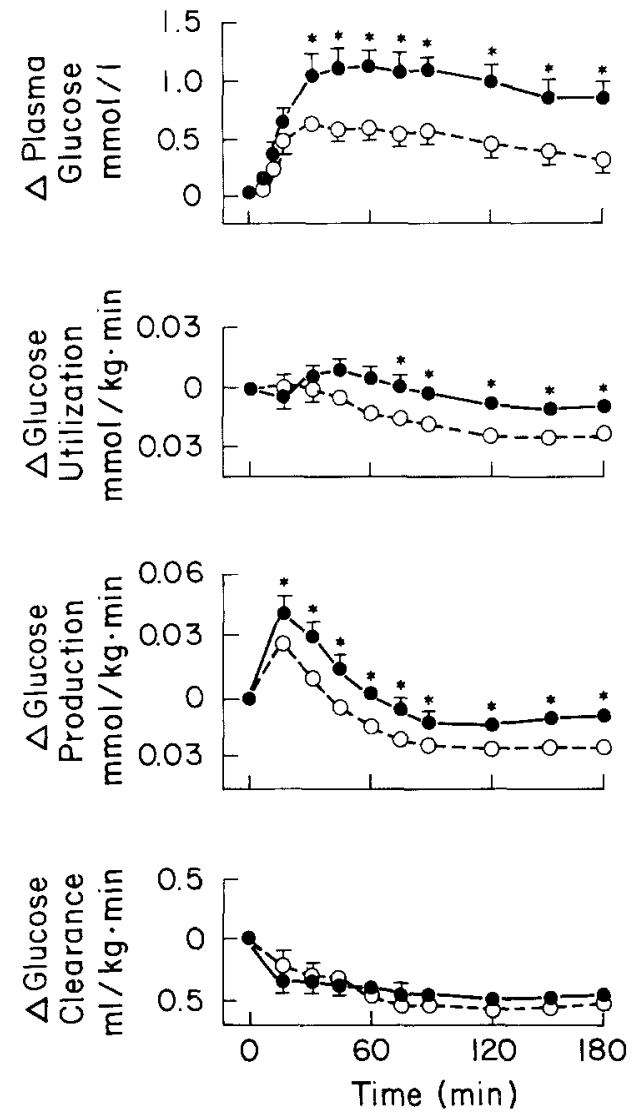

Fig. 6. Change in plasma glucose, glucose production, glucose utilization, and glucose clearance rate in young $\left(\mathrm{O}_{--} \mathrm{O}\right)$ and older (-) subjects following intravenous glucagon infusion (3 $\mathrm{ng}$. $\mathrm{kg}^{-1} \cdot \min ^{-1}$ ). All values represent the mean \pm SEM. (SEM bars are not depicted when the SEM is smaller than the size of the symbol used to designate the particular value). $* p<0.05$ (young versus old)

\section{Glucagon Infusion}

Ten young and eight older subjects were studied with a 3 - $\mathrm{h}$ infusion of glucagon at $3 \mathrm{ng} \cdot \mathrm{kg}^{-1} \cdot \mathrm{min}^{-1}$ (Fig. 5). There were no significant differences in the steady-state plasma glucagon concentrations $(267 \pm 32$ versus $252 \pm$ $12 \mathrm{pg} / \mathrm{ml}$ ) between the two groups. The metabolic clearance rates of glucagon were also comparable in the young and older subjects (16 \pm 1 versus $15 \pm 1 \mathrm{ml}$. $\mathrm{kg}^{-1} \cdot \min ^{-1}$ ).

Fasting plasma insulin levels were similar in young and older subjects $(13 \pm 1$ versus $11 \pm 1 \mathrm{mU} / \mathrm{l})$. Within 10 min of starting the glucagon infusion, a small, transient rise in plasma insulin concentration was observed in both groups; this was followed by a gradual return to basal levels by $120 \mathrm{~min}$ (Fig. 5). The increase in plasma insulin concentration was similar in young and older subjects at all times during the infusion.

The fasting plasma glucose concentration was similar in young and older subjects $(4.83 \pm 0.06$ and $5.06 \pm$ $0.11 \mathrm{mmol}$ respectively). Following glucagon the maximal rise in plasma glucose concentration in older subjects $(1.17 \pm 0.11 \mathrm{mmol} / 1)$ was significantly greater than in the young $(0.67 \pm 0.06 \mathrm{mmol} / 1, p<0.01$; Fig. 6$)$. This difference was evident by 30 min and persisted until the end of the glucagon infusion at $180 \mathrm{~min}$. Basal hepatic glucose production was slightly higher in the young subjects $\left(0.15 \pm 0.01 \mathrm{mmol} \cdot \mathrm{kg}^{-1} \cdot \mathrm{min}^{-1}\right)$ than in the older subjects $\left(0.13 \pm 0.01 \mathrm{mmol} \cdot \mathrm{kg}^{-1} \cdot \mathrm{min}^{-1}\right)$. Maximum increase in glucose production was attained within $15 \mathrm{~min}$ following glucagon administration in both young and older subjects. This initial increment in glucose production was higher in older subjects than in young $\left(0.04 \pm 0.01\right.$ versus $0.03 \pm 0.01 \mathrm{mmol} \cdot \mathrm{kg}^{-1}$. $\min ^{-1}$; Fig. 6). After $15 \mathrm{~min}$, glucose production began to decline in both young and older groups, but the increment in hepatic glucose production remained significantly higher in the older subjects at all time points $(p<0.05)$. By $75 \mathrm{~min}$, glucose production had decreased to below basal levels in both groups, a greater decrease being observed in the young subjects at all time intervals.

In the basal state glucose utilization which, by definition, must equal glucose production, was slightly higher in the young subjects. After glucagon infusion, there was little change in glucose utilization in either young or older subjects. However, from 30 min until termination of the study at $180 \mathrm{~min}$, the change in glucose utilization was significantly greater in the older compared with the young group (Fig.6). Since the plasma glucose concentration was higher in the older group, the change in the metabolic clearance rate of glucose (Fig.6) was similar in young and older subjects. Thus, the greater increment in plasma glucose concentration observed following glucagon infusion in the older group cannot be explained by a lower rate of glucose utilization or glucose clearance.

\section{Discussion}

Recent studies have suggested that increased glucagon secretion and/or enhanced tissue sensitivity to glucagon may play an important role in glucose intolerance in diabetes mellitus [17-19], uraemia [20], cirrhosis [21], trauma [22], infection [23], and pancreatitis [24]. Although the normal aging process is known to be associated with a decrease in glucose tolerance [1-5], few studies have examined what effect age-related changes in glucagon metabolism may play in the impaired carbohydrate utilization.

Two groups have examined the effect of age on fasting plasma glucagon levels. Dudl and Ensinck [4] failed to find any changes in fasting glucagon concentration throughout the entire adult age span. Similarly, Berger et al. [6] reported no difference in basal immunoreactive glucagon in subjects between 30 and 69 years, although they did find lower fasting values in 20-29 year old subjects compared with those over 30 years of age. In a preliminary study, Marco et al. [7] reported slightly higher fasting plasma glucagon levels in elderly versus young subjects. The precise age range, however, was not 
given and it is not clear whether the lower fasting glucagon concentrations occurred only in the youngest ( $<30$ years) subjects as reported by Berger et al. [6] or whether there was a progressive increase throughout the entire age span. In the present study, we failed to demonstrate any age-related change in fasting plasma glucagon. Taken with the published results of Berger et al. [6] and Dudl and Ensinck [4], it would appear that after the age of 30 years, there is little, if any, change in postabsorptive plasma glucagon levels. Whether or not fasting glucagon concentrations are lower in subjects under the age of 30 years is still open to question.

Impaired suppression of glucagon during hyperglycaemia has been suggested as a possible contributing factor to glucose intolerance in states such as diabetes mellitus [17, 18] and uraemia [20], but little data has been collected on glucagon suppressability with aging. Marco et al. reported that young subjects (aged 1923 years) exhibited a suppression of basal glucagon levels from 135 to $105 \mathrm{pg} / \mathrm{ml}$, whereas older subjects (aged 65-90 years) actually demonstrated a small rise in glucagon levels from their basal levels of $193 \mathrm{pg} / \mathrm{ml}$ after an oral glucose load [7]. However, changes in plasma glucagon following oral glucose administration are difficult to interpret since variable gastrointestinal absorption as well as differences in glucose disposal will result in varying degrees of hyperglycaemia, and the release of gastrointestinal hormones following oral glucose might affect glucagon secretion per se. The glucose clamp technique offers the opportunity to investigate glucagon suppression during constant hyperglycaemia while also avoiding any effects that gastrointestinal hormones might have on glucagon release. Furthermore, the hyperglycaemic plateaus employed in this study $(+2.2$ and $+6.9 \mathrm{mmol} / \mathrm{l})$ are representative of the full physiological range of glucose levels to which the pancreatic $\alpha$ cell may be exposed. At each of these hyperglycaemic levels, the suppression of plasma glucagon was similar in young, middle-aged, and older subjects. In this respect, the glucose intolerance of aging does not resemble the impaired carbohydrate metabolism of diabetes mellitus where impaired glucagon suppression has been described $[17,18]$.

It is also noteworthy that the absolute falls $(35 \pm 10$, $35 \pm 6$, and $34 \pm 4 \mathrm{pg} / \mathrm{ml}$ ) as well as the percentage falls $(37 \pm 7,39 \pm 7$, and $41 \pm 4 \%)$ in plasma glucagon during the +2.2 and $+6.9 \mathrm{mmol} / 1$ hyperglycaemic clamp studies respectively were similar. These results indicate that the $\alpha$ cell of normal individuals is exquisitely sensitive to very small elevations in plasma glucose concentration. A rise in plasma glucose concentration of only $2.2 \mathrm{mmol} / 1$ elicits maximal suppression of glucagon secretion. Further elevations in plasma glucose concentration within the physiological range (up to $6.9 \mathrm{mmol} / \mathrm{l}$ above fasting) resulted in no additional decrease in circulating glucagon levels. During the euglycaemic insulin clamp study, the absolute decline in plasma glucagon levels $(25 \pm 3$ and $27 \pm 3 \mathrm{pg} / \mathrm{ml}$ in young and older subjects) was similar to that observed with the hyperglycaemic clamp. This indicates that hyperglycaemia is not necessary for normal glucagon suppression and suggests that insulin per se or some insulin-mediated intracellular process is sufficient for the suppression of $\alpha$ cell function. It should be noted that the present studies do not exclude the possiblity that hyperglycaemia per se may have its own suppressive effect on glucagon secretion independent of changes in plasma insulin levels.

While hyperglycaemic suppression of glucagon may not be impaired with age, it has recently been reported that older subjects exhibit a significantly greater rise in plasma glucagon than young subjects after an intravenous infusion of arginine [7]. Furthermore, an enhanced $\alpha$ cell response to aminogenic stimulation has also been observed in certain other glucose intolerant states including diabetes mellitus [19,20], cirrhosis [21], pancreatitis [24], and obesity [25-27]. However, we observed no significant differences in the maximal increments of glucagon or glucose between the old and young groups. The maximal increase in plasma glucose after alanine administration was similar in old and young subjects, but hyperglycaemia persisted for considerably longer in the older subjects. This impaired restoration of fasting glucose levels after an elevation of plasma glucose is consistent with the significantly lower metabolic clearance rate of glucose found in the older subjects during the glucagon infusion studies. Since the plasma insulin response in older subjects was equal to or slightly greater than that of young subjects at all times, the impaired return of plasma glucose concentration to basal levels suggests the presence of insulin resistance in the older subjects. Studies by DeFronzo employing the insulin clamp technique have demonstrated impaired tissue sensitivity to insulin with advancing age [28]. It has also been shown that insulin resistance contributes to the glucose intolerance of diabetes mellitus [29,30], obesity [31], and uraemia [20].

Alterations in tissue sensitivity to glucagon in aging man have not been examined previously. In the present study, the plasma glucose response to glucagon, as well as the increase in hepatic glucose production, were significantly greater in older subjects. Few studies have examined the mechanisms of enhanced hepatic sensitivity at the cellular level. In the rat, Blazquez et al. have shown that the adenylate cyclase response to glucagon rises steadily throughout prenatal life and does not reach adult levels until day 30 of post-natal life. This increase in glucagon sensitivity in the older rats was directly correlated with an increase in glucagon binding to hepatocytes [32]. In contrast, Lockwood et al. observed a decline in glucagon binding during aging in rat adipocytes [33], but not hepatocytes [34]. Similar studies examining age-related changes in glucagon binding or cyclic AMP generation in man might be helpful in delineating the increased hepatic sensitivity to glucagon with age that was observed in the present study.

In summary, the present studies clarify several im- 
portant concepts about changes in glucagon physiology with advancing age: (1) basal levels of glucagon are not elevated in older subjects; (2) glucagon suppression by both hyperglycaemia and hyperinsulinaemia are similar in older and young subjects; (3) $\alpha$ cell sensitivity to alanine is not affected by age; (4) the metabolic clearance rate of glucagon is similar in young and older subjects; and (5) hepatic sensitivity to a physiological increment in plasma glucagon is enhanced in older individuals. Thus, glucagon may contribute to the glucose intolerance of aging via alteration in tissue sensitivity rather than increased secretion, but the cellular mechanism of this effect remains to be established.

Acknowledgements. The authors would like to thank Dr. R. Hendler and Mrs. A. Belous for performing the glucagon and insulin radioimmunoassays, and Mrs. L. Mishiwiec for expert assistance in performing the studies. Dr. R. Sherwin provided critical review during the preparation of the manuscript. Ms. L.O. Derbacher provided expert secretarial help. This work was supported by the National Institutes of Health research grant AG-00764.

\section{References}

1. Andres R (1971) Aging and diabetes. Med Clin N Am 55:835-846

2. Hayner NS, Kjelsberg MO, Epstein FH, Francis T (1965) Carbohydrate tolerance and diabetes in a total community, Tecumseh, Michigan. 1.Effects of age, sex, and test conditions on one-hour glucose tolerance in adults. Diabetes 14: 413-423

3. O'Sullivan JB, Mahan CM, Freedlender AE, Williams RF (1971) Effect of age on carbohydrate metabolism. J Clin Endocrinol 33: 619-623

4. Dudl RJ, Ensinck JW (1977) Insulin and glucagon relationships during aging in man. Metabolism 26: 33-41

5. Duckworth WC, Kitabchi AE (1976) The effect of age on plasma proinsulin-like material after oral glucose. J Lab Clin Med 88: 359-367

6. Berger D, Crowther R, Floyd JC, Pek S, Fajans SS (1978) Effects of age on fasting levels of pancreatic hormones in man. J Clin Endocrinol Metab 47: 1183-1189

7. Marco J, Hedo JA, Villanueva ML (1977) Hyperglucagonism in the elderly. Diabetes 26:381 (Abstract)

8. McGuire EAH, Helderman JH, Tobin JD, Andres R, Berman M (1976) Effects of arterial versus venous sampling. An analysis of glucose kinetics in man. J Appl Physiol 41: 565-573

9. DeFronzo RA, Tobin JD, Rose JW, Andres R (1978) Glucose intolerance in uremia: Quantification of pancreatic beta cell sensitivity to glucose and tissue sensitivity to insulin. J Clin Invest 62 : $425-435$

10. Sherwin RS, Kramer KJ, Tobin ID, Insel PA, Liljenquist JE, Berman M, Andres R (1974) A model of the kinetics of insulin in man. J Clin Invest 53: 1481-1492

11. Wise JK, Hendler R, Felig P (1973) Influence of glucocorticoids on glucagon secretion and plasma amino acid concentrations in man. J Clin Invest 52: 2774-2782

12. Sherwin RS, Hendler R, DeFronzo RA, Wahren JA, Felig P(1977) Glucose homeostasis during prolonged suppression of glucagon and insulin secretion by somatostatin. Proc Natl Acad Si, USA 74: $348-352$

13. Steele R (1959) Influence of glucose loading and of injected insulin on hepatic glucose output. Ann NY Acad Sci 82: 420-430

14. Cowan JS, Hetenyi C (1971) Glucoregulatory responses in normal and diabetic dogs recorded by a new tracer method. Metab Clin $\operatorname{Exp} 20: 360-372$

15. Radziuk J, Norwich KH, Vranic M (1974) Measurement and validation of nonsteady state turnover rates with application to the insulin and glucose systems. Fed Proc 33: 1855-1864
16. Snedecor GW, Cochran WG (1967) Statistical Methods. 6th edn. Iowa State University Press, Ames, lowa

17. Gerich JE, Langlois M, Noacco C, Lorenzi M, Karam JH, Forsham PH, Gustafson G (1976) Comparison of the suppressive effects of elevated plasma glucose and free fatty acid levels on glucagon secretion in normal and insulin-dependent diabetic subjects. J Clin Invest 58:320-325

18. Muller WA, Faloona GR, Aguilar-Parada E, Unger RH (1970) Abnormal alpha cell function in diabetes: response to carbohydrate and protein ingestion. N Engl J Med 283: 109-115

19. Unger RH, Aguilar-Parada E, Muller WA, Eisentraut AM (1970) Studies of pancreatic alpha cell function in normal and diabetic subjects. J Clin Invest 49:837-848

20. Sherwin RS, Bastl C, Finkelstein FO, Fisher M, Black H, Hendler R, Felig P (1976) Influence of uremia and hemodialysis on the turnover and metabolic effects of glucagon. J Clin Invest 57 : $722-731$

21. Sherwin R, Joshi P, Hendler R, Felig P, Conn HO (1974) Hyperglucagonemia in Laennec's cirrhosis: The role of porto-systemic shunting. N Engl J Med 290: 239-242

22. Lindsey A, Santeusanio F, Braaten J, Faloona GR, Unger RH (1974) Pancreatic alpha-cell function in trauma. J Am Med Assoc 227: 757-761

23. Rocha DM, Santeusanio F, Faloona GR, Unger RH (1973) Abnormal pancreatic alpha-cell function in bacterial infections. $\mathrm{N}$ Engl J Med 288: 700-703

24. Donowitz M, Hendler R, Spiro HM, Binder HJ, Felig P (1975) Glucagon secretion in acute and chronic pancreatitis. Ann Int Med 83: 778-781

25. Unger RH, Lefebvre P (1972) Glucagon: In: Lefebvre JP, Unger RH (eds) Molecular physiology, clinical and therapeutic implications. Pergamon Press, New York, pp 229-238

26. Wise JK, Hendler R, Felig P (1973) Evaluation of alpha-cell function by infusion of alanine in normal, diabetic, and obese subjects. N Engl J Med 288: 484-487

27. Kalkhoff RK, Gossain VV, Matute ML (1973) Plasma glucagon in obesity: Response to arginine, glucose, and protein administration. N Engl J Med 289: 465 467

28. DeFronzo RA (1979) Glucose intolerance and aging. Evidence for tissue insensitivitiy to insulin. Diabetes 28: 1095-1101

29. DeFronzo RA, Diebert D, Hendler R, Felig P, Soman V (1979) Insulin sensitivity and insulin binding to monocytes in maturity-onset diabetes. I Clin Invest 63:939-946

30. Ginsberg H, Kimmerling G, Olefsky JM, Reaven GM (1975) Demonstration of insulin resistance in untreated adult onset diabetic subjects with fasting hyperglycemia. J Clin Invest 55: 454461

31. DeFronzo RA, Soman V, Sherwin RS, Hendler R, Felig P (1978) Insulin binding to monocytes and insulin action in human obesity, starvation, and refeeding. $J$ Clin Invest $62 ; 204-213$

32. Blazquez E, Rubalcava B, Montesano R, Orci L, Unger R (1976) Development of insulin and glucagon binding and the adenylate cyclase response in liver membranes of the prenatal, postnatal, and adult rat: Evidence of glucagon 'resistance'. Endocrinol 98: 1014-1023

33. Livingston JN, Cuatrecasas P, Lockwood DH (1974) Studies of glucagon resistance in large rat adipocytes: ${ }^{125}$-labeled glucagon binding and lipolytic capacity. J Lipid Res 15:26

34. Lockwood DH, East LE (1978) [ ${ }^{125} \mathrm{I}$-glucagon binding by liver membranes from young and adult rats. Diabetes $27: 589-591$

Received: 16 August 1982

and in revised form: 14 February 1983

\section{Dr. Ralph A. DeFronzo}

2074 LMP

Yale University School of Medicine

333 Cedar Street

New Haven, Connecticut 06510

USA 